\section{Immunology of infusion reactions in the treatment of patients with acute lymphoblastic leukemia}

\author{
Barbara Asselin*
}

\begin{abstract}
Infusion reactions are potentially dose-limiting adverse events associated with intravenous administration of several common agents used to treat patients with acute lymphoblastic leukemia. True clinical hypersensitivity reactions are antibody-mediated and can occur only after repeated exposure to an antigen. Conversely, anaphylactoid infusion reactions are nonantibody-mediated and often occur on the initial exposure to a drug. Cytokine-release syndrome comprises a subset of nonantibody-mediated infusion reactions associated with the use of monoclonal antibodies and immune therapies. Clinical symptoms of hypersensitivity reactions and nonantibody-mediated infusion reactions heavily overlap and can be difficult to distinguish in practice. Regardless of the underlying mechanism, any infusion reaction can negatively affect treatment efficacy and patient safety. These events require prompt response, and potentially, modification of subsequent therapy.
\end{abstract}

First draft submitted: 4 January 2016; Accepted for publication: 5 March 2016; Published online: 18 April 2016

Acute lymphoblastic leukemia (ALL) is a life-threatening, potentially fatal hematological malignant disorder and the most common form of leukemia in pediatrics. It is estimated that 6000 new cases of ALL are diagnosed each year in USA, with the majority of new diagnoses in patients aged $<20$ years [1-3]. Successful treatment of both adult and pediatric patients with ALL spans years and is composed of several distinct phases of multiagent chemotherapy [3,4]. Although treatment outcomes have greatly improved over the past decades, a number of barriers remain $[5,6]$. Several chemotherapeutic agents widely used in ALL have been associated with infusion reactions [7-12]. There exists a variety of infusion reactions in the treatment of patients with ALL that share a common cause from activation of the immune system, yet each reaction type requires a different management approach. Clinical hypersensitivity reactions are antibody-mediated reactions that can occur after repeated exposure to a drug. Nonantibody-mediated infusion reactions (often referred to as anaphylactoid reactions in the literature) occur independent of the development of antidrug antibodies, can occur on a patient's first exposure and often are characterized by symptoms very similar to clinical hypersensitivity reactions. Cytokine-release syndrome (CRS) is a specific type of nonantibody-mediated infusion reaction that is associated with monoclonal antibodies and T-cell-directed therapies [13-15].

The likelihood and severity of an infusion reaction can vary dependent upon the drug and patient, but all immune responses share the potential for adverse treatment-related events and may negatively impact outcomes [16-18]. Understanding the physiological mechanisms underlying the different types of immune reactions will ensure that physicians are prepared to adequately respond with appropriate treatment management, potentially prolonging treatment duration and improving

*Golisano Children's Hospital, University of Rochester Medical Center, 601 Elmwood Avenue, Box 667, Rochester, NY, USA;

*Golisano Children's Hospital, University of Rochester Medica 585 276 4113; Barbara_Asselin@URMC.Rochester.edu

\section{KEYWORDS}

- allergy • anaphylactoid reaction • asparaginase - cytokine-release syndrome $\bullet$ hypersensitivity - monoclonal antibody

- silent inactivation 
long-term outcomes in patients with ALL. The goal of this review is to provide an overview of the basic immunology associated with infusion reactions in patients with ALL.

\section{Infusion reactions $\&$ the role of the immune system}

Intravenously administered chemotherapeutic agents, including asparaginase and monoclonal antibodies, are a ubiquitous component of multiagent chemotherapy regimens used to treat patients with ALL. However, infusion reactions, which may result from an excessive reaction produced by a normal immune system, are a potentially dose-limiting adverse event, affecting safety and outcomes.

These infusion reactions result from an immune response that can arise from innate or adaptive mechanisms [19]. An innate immune response can be elicited without any prior exposure to an antigen; however, an adaptive immune response requires previous exposure to elicit a clinical reaction [20]. The likelihood of eliciting an adaptive immune reaction increases with repeated exposure to an antigen. On a patient's first exposure, and at every subsequent exposure, there exists the potential that B-cell activation will lead to the production of antibodies that will specifically target the offending antigen during subsequent exposure [11,19].

Clinical hypersensitivity reactions (also referred to as allergic reactions) are produced by the adaptive immune system and are antibody mediated. The immune cascade responsible for hypersensitivity reactions involves a number of different immune mediators, some cellular and some soluble chemical substances. A brief summary of the major components of the immune system and the role they play in hypersensitivity reactions can be found in Table 1 [21]. Antibodies and mast cells are central to the physiology underlying clinical hypersensitivity reactions, such as classic allergy or anaphylaxis [7,22]. When presented with an antigen, circulating antigen-specific B cells may be activated to produce antigen-specific antibodies. All antibodies display a characteristic shape and structure [19]. This structure is comprised of a variable antigenspecific binding site and a constant region, which is able to bind and interact with other immune cells $[11,23]$.

There are several different types of antibody classes, and each class plays a unique role in the host response to an antigen. The antibody class thought to be most directly involved with clinical hypersensitivity reactions is the $\operatorname{IgE}$ antibody class [7,22], although clinical evidence suggests increased concentrations of IgM and IgG occur in ALL patients with hypersensitivity reactions to asparaginase [11,24-26]. Mast cells and basophils have high affinity receptors on their cell surface specifically for the constant region of the IgE class of antibodies [19]. When IgE antibodies are bound to mast cells in the presence of a specific antigen, mast-cell degranulation is triggered, releasing immune mediators, such as histamines, leukotrienes and prostaglandins [7,22]. The total amount of mediator released from mast cells is a function of the concentration of $\operatorname{IgE}$ antibodies bound to the mast cells and the serum concentration of the antigen [27]. Although antibody/antigen concentration is the primary factor in determining the amount of mediator released, a number of other nonspecific factors also may play a role. These factors include infection, physical activity, psychological stress and concomitant medications [27]. Furthermore, a subset of patients has been shown to develop antidrug antibodies in the absence of any overt clinical symptoms of allergy, a condition termed subclinical hypersensitivity or 'silent inactivation' $[16,18,28,29]$. While these patients do not display clinical hypersensitivity reactions, the presence of circulating antidrug antibodies can substantially influence drug pharmacokinetics [30] and may have a negative effect on treatment efficacy and outcomes [16,18]. This phenomenon has been observed with asparaginase therapy $[16,18]$.

Conversely, there are infusion reactions, which result from an innate immune response, are transient nonantigen specific, do not require the presence of antidrug antibodies and differ in important ways from a true antibody-mediated response [7]. Since they are not antibody dependent, they do not require prior exposure to 'prime' or sensitize the immune system. The exact mechanisms by which chemotherapeutic agents elicit an infusion reaction are not fully known and may result from several factors, including direct cytokine release, activation of the complement system, activation of the coagulation system and, in the case of asparaginase, a sharp spike in ammonia levels [26,27,31,32]. Monoclonal antibodies (rituximab, epratuzumab among others) and T-cell-engaging therapies (blinatumomab and chimeric antigen receptor-specific [CAR] T-cell therapy) are examples of treatments that 
Table 1. Relevant immune mediators.

\begin{tabular}{|c|c|}
\hline $\begin{array}{l}\text { Immune cells and } \\
\text { soluble mediators }\end{array}$ & Major function(s) \\
\hline Antigen & $\begin{array}{l}\text { Any substance that elicits an immune response and is immunogenic; immune } \\
\text { system recognizes as harmful or foreign substance }\end{array}$ \\
\hline Dendritic cell & Antigen uptake; presents antigen to T cells (antigen-presenting cell) \\
\hline B cell & $\begin{array}{l}\text { Presents antigen (antigen-presenting cell); differentiates into plasma cells; produces } \\
\text { antibodies }\end{array}$ \\
\hline Antibody & Proteins produced by B cells specifically to recognize antigen \\
\hline TH2 cell & $\begin{array}{l}\text { Source of IL-4 that is responsible for driving the synthesis of IgE rather than other } \\
\text { classes of immunoglobulins from antigen-activated B cells }\end{array}$ \\
\hline Mast cell & $\begin{array}{l}\text { Triggers local inflammatory responses to antigen by releasing granules containing } \\
\text { histamine and active agents }\end{array}$ \\
\hline Cytokines & $\begin{array}{l}\text { Soluble mediators released by cells to communicate with other cells (generally } \\
\text { either promote or inhibit inflammation) }\end{array}$ \\
\hline Complement & $\begin{array}{l}\text { Soluble, inactive precursors. When activated, coats the antigen making it } \\
\text { recognizable by macrophages to engulf }\end{array}$ \\
\hline
\end{tabular}

have been associated with a type of nonantibodymediated infusion reaction known as CRS [33-38]. Such reactions, increasingly recognized with the growing availability and use of monoclonal antibodies and immune-modulating therapies, result from direct release of histamine and other cytokines from mast cells and direct activation of the complement system [33]. The risk of occurrence is not dependent on the frequency of exposure and generally diminishes with repeated exposure. In fact, the severity of some nonantibody-mediated infusion reactions has been shown to be directly related to disease burden at the time of exposure; thus, these reactions are often most severe and likely to occur with a patient's first exposure $[39,40]$.

\section{Presenting signs \& symptoms of infusion reactions}

The clinical symptoms of these infusion or immune reactions can vary greatly and will depend on a number of factors. Potential symptoms from reactions heavily overlap and cannot be used as a reliable method for distinguishing these reactions. The Common Terminology Criteria for Adverse Events (CTCAE) version 4.03 guidelines for reporting and grading severity of adverse events distinguish among different types of immune reactions associated with cancer treatments (Table 2); however, the similarity in presentation limits the usefulness of these criteria for distinguishing among reaction types [34]. For the purposes of this discussion, the term 'hypersensitivity' is used to indicate the antibody-mediated phenomena of allergy and anaphylaxis versus nonantibody-mediated reactions defined as infusion-related reactions or CRSs in the most recent version of the CTCAE [34]. These different types of immune reactions to chemotherapeutic drugs will be described in detail in the text below.

\section{- Clinical hypersensitivity}

Symptoms of clinical hypersensitivity are diverse and can range from a mild skin rash to more severe reactions, including wheezing and difficulty breathing, hypotension, poor perfusion, respiratory arrest and rarely, death [7,9,22,41-43]. Table 3 highlights commonly observed symptoms of hypersensitivity reactions in patients across various organ systems [7,22,41-44].

Anaphylaxis, a potentially life-threatening condition characterized by systemic mast-cell activation, can occur within seconds following the initiation of an infusion $[45,46]$. In fact, the severity of anaphylaxis has been found to be directly related to the immediacy of occurrence [46]. Clinical symptoms of anaphylaxis include swelling, angioedema, bronchospasm, respiratory distress, hypotension, shock and organ-system failure $[21,45]$. Nonanaphylatic clinical hypersensitivity reactions usually occur within the first hour following drug administration; however, more delayed responses have been reported $[11,47,48]$. The early-phase symptoms of hypersensitivity are the result of mast-cell degranulation and the immediate release of histamine and other immunomediators. This leads to vasodilation, increase 
Table 2. Grading of adverse events associated with infusion reactions (Common Terminology Criteria for Adverse Events v4.03)

\begin{tabular}{|c|c|c|c|c|c|}
\hline \multirow[t]{2}{*}{ Adverse event } & \multicolumn{5}{|c|}{ Grade } \\
\hline & 1 & 2 & 3 & 4 & 5 \\
\hline \multicolumn{6}{|c|}{ General disorders \& administration site conditions } \\
\hline $\begin{array}{l}\text { Infusion-related } \\
\text { reaction }\end{array}$ & $\begin{array}{l}\text { Mild transient } \\
\text { reaction; infusion } \\
\text { interruption not } \\
\text { indicated; intervention } \\
\text { not indicated }\end{array}$ & $\begin{array}{l}\text { Therapy or infusion interruption } \\
\text { indicated but responds promptly } \\
\text { to symptomatic treatment } \\
\text { (e.g., antihistamines, NSAIDs, } \\
\text { narcotics, iv. fluids); prophylactic } \\
\text { medications indicated for } \leq 24 \mathrm{~h}\end{array}$ & $\begin{array}{l}\text { Prolonged (e.g., not rapidly } \\
\text { responsive to symptomatic } \\
\text { medication and/or brief } \\
\text { interruption of infusion); } \\
\text { recurrence of symptoms } \\
\text { following initial improvement; } \\
\text { hospitalization indicated for } \\
\text { clinical sequelae }\end{array}$ & $\begin{array}{l}\text { Life-threatening } \\
\text { consequences; } \\
\text { urgent intervention } \\
\text { indicated }\end{array}$ & Death \\
\hline \multicolumn{6}{|c|}{ Immune system disorders } \\
\hline Allergic reaction & $\begin{array}{l}\text { Transient flushing } \\
\text { or rash, drug fever } \\
<38^{\circ} \mathrm{C}\left(<100.4^{\circ} \mathrm{F}\right) \text {; } \\
\text { intervention not } \\
\text { indicated }\end{array}$ & $\begin{array}{l}\text { Intervention or infusion } \\
\text { interruption indicated; responds } \\
\text { promptly to symptomatic } \\
\text { treatment (e.g., antihistamines, } \\
\text { NSAIDs, narcotics); prophylactic } \\
\text { medications indicated for } \leq 24 \mathrm{~h}\end{array}$ & $\begin{array}{l}\text { Prolonged (e.g., not rapidly } \\
\text { responsive to symptomatic } \\
\text { medication and/or brief } \\
\text { interruption of infusion); } \\
\text { recurrence of symptoms } \\
\text { following initial improvement; } \\
\text { hospitalization indicated for } \\
\text { clinical sequelae (e.g., renal } \\
\text { impairment, pulmonary } \\
\text { infiltrates) }\end{array}$ & $\begin{array}{l}\text { Life-threatening } \\
\text { consequences; } \\
\text { urgent intervention } \\
\text { indicated }\end{array}$ & Death \\
\hline Anaphylaxis & - & - & $\begin{array}{l}\text { Symptomatic bronchospasm, } \\
\text { with or without urticaria; } \\
\text { parenteral intervention } \\
\text { indicated; allergy-related } \\
\text { edema/angioedema; } \\
\text { hypotension }\end{array}$ & $\begin{array}{l}\text { Life-threatening } \\
\text { consequences; } \\
\text { urgent intervention } \\
\text { indicated }\end{array}$ & Death \\
\hline $\begin{array}{l}\text { Cytokine- } \\
\text { release } \\
\text { syndrome }\end{array}$ & $\begin{array}{l}\text { Mild reaction; infusion } \\
\text { interruption not } \\
\text { indicated; intervention } \\
\text { not indicated }\end{array}$ & $\begin{array}{l}\text { Therapy or infusion interruption } \\
\text { indicated but responds promptly } \\
\text { to symptomatic treatment } \\
\text { (e.g., antihistamines, NSAIDs, } \\
\text { narcotics, iv. fluids); prophylactic } \\
\text { medications indicated for } \leq 24 \mathrm{~h}\end{array}$ & $\begin{array}{l}\text { Prolonged (e.g., not rapidly } \\
\text { responsive to symptomatic } \\
\text { medication and/or brief } \\
\text { interruption of infusion); } \\
\text { recurrence of symptoms } \\
\text { following initial improvement; } \\
\text { hospitalization indicated for } \\
\text { clinical sequelae (e.g., renal } \\
\text { impairment, pulmonary } \\
\text { infiltrates) }\end{array}$ & $\begin{array}{l}\text { Life-threatening } \\
\text { consequences; } \\
\text { pressor or } \\
\text { ventilatory support } \\
\text { indicated }\end{array}$ & Death \\
\hline
\end{tabular}

in vascular permeability, platelet aggregation and degranulation and contraction of smooth muscle (e.g., the 'wheal and flare' reaction) [21].

The administration of any sufficiently large foreign protein is likely to elicit some degree of immune response from a host [49]. Thus, asparaginase frequently is associated with clinically significant immune responses in patients undergoing chemotherapy for ALL [16-18]. The risk of developing antidrug antibodies, and thereby the risk of displaying a clinical hypersensitivity reaction, is dependent on a number of factors, including stage of therapy, patient genetics, previous drug exposure, route of administration and drug formulation [30]. Until recently, asparaginase was primarily administered via a series of intramuscular (im.) injections in the USA due to concern for higher rates of hypersensitivity reactions observed with intravenous (iv.) administration [50]; however, iv. administration is now approved for all formulations. Hypersensitivity reactions can occur significantly earlier following iv. infusions compared with im. injection [51,52].

Clinical trials have shown that incidence of antiasparaginase antibodies is greater during the intensification and reinduction stages 
of treatment, during which patients had been exposed to multiple doses of asparaginase [25,53,54]. Antibody development has been implicated as a predictor of future clinical hypersensitivity in patients undergoing asparaginase treatment for ALL [55]. Liu et al. evaluated the relationship between antiasparaginase antibodies and clinical hypersensitivity reactions in standard- and highrisk ALL patients treated according to St Jude Total XV protocol [55]. The investigators observed that hypersensitivity reactions and antiasparaginase-antibody titers were significantly higher among patients treated on the low-risk arm compared with patients treated on the standard/highrisk arm. These results support the notion that high-intensity chemotherapy may reduce the risk of immune reactions in patients [18,30,56-58].

The risk of hypersensitivity to asparaginase differs depending on the formulation administered. Three different types of asparaginase have been approved for use in the treatment of patients with ALL in the USA. Native Escherichia coli asparaginase and pegylated (PEG)-asparaginase are derived from the bacterium E. coli. The third product, asparaginase Erwinia chrysanthemi is derived from the bacterium E. chrysanthemi. Production of native E. coli asparaginase has been discontinued in the USA and has been replaced with PEG-asparaginase as first-line therapy [59]. Compared with native E. coli asparaginase, antibody formation and clinical hypersensitivity reactions with asparaginase $E$. chrysanthem $i$ and PEG-asparaginase are less prevalent, with studies reporting hypersensitivity reactions in $2-18 \%$ of patients treated with PEG-asparaginase $[56,60]$ and $6-37 \%$ with asparaginase E. chrysanthemi (see case study 1 below) $[51,53,61]$.

Patient genetics may also play a role in determining the likelihood that a patient will display a clinical hypersensitivity reaction. Using a genome-wide approach, Chen et al. reported that genetic variations in GRIA1 were associated with asparaginase allergy [62]. Additionally, hypersensitivity reactions were found to occur at a higher frequency in patients of Caucasian ancestry compared with black or Hispanic children [62]. Fernandez et al. have identified a specific variant of the NFATC2 gene that was associated with a significantly greater risk of asparaginase hypersensitivity in children with ALL [63]. In addition to establishing a clear genetic risk factor for asparaginase hypersensitivity, this research supports an important role of $\mathrm{T}$ cells in the immune cascade responsible for asparaginase hypersensitivity.

A subset of patients undergoing asparaginase therapy will develop antidrug antibodies without displaying any overt symptoms of clinical hypersensitivity. This condition, known as subclinical hypersensitivity (also referred to as 'silent inactivation'), is associated with reduced asparaginase activity levels and poor outcomes if left untreated $[30,64,65]$. As many as $29 \%$ of high-risk ALL patients treated on the CCG-1961 pediatric protocol developed subclinical hypersensitivity to $E$. coli-derived asparaginase [18]. In a recent prospective monitoring study, $8 \%$ of patients developed subclinical hypersensitivity to PEG-asparaginase and subsequently showed no detectable asparaginase activity levels [66]. The risk of subclinical hypersensitivity has been found to be even greater at the time of relapse and can be difficult to identify due to the lack of clinical symptoms $[67,68]$. The real-time measurement of asparaginase activity levels is increasingly used to identify patients with subclinical hypersensitivity $[30,66]$.

\section{- Nonantibody-mediated infusion reactions} Not all clinical immune responses are antibody mediated. Anaphylactoid infusion reactions

Table 3. Clinical signs and symptoms of hypersensitivity reactions.

\begin{tabular}{|c|c|}
\hline System & Signs or symptoms \\
\hline General & Fever, chills, flushing, rigors, sweating, fatigue, agitation, metallic taste \\
\hline Cutaneous & $\begin{array}{l}\text { Rash, urticaria (hives, welts, wheals) pruritus, angioedema (including face, lips or } \\
\text { eyelids) }\end{array}$ \\
\hline Respiratory & $\begin{array}{l}\text { Dyspnea, wheezing, stridor, rhinitis, repetitive cough, chest tightness, throat } \\
\text { tightness, change in voice quality (from laryngeal edema) }\end{array}$ \\
\hline Cardiovascular & Tachycardia, hypotension/hypertension \\
\hline Gastrointestinal & Nausea, vomiting, diarrhea, abdominal cramping \\
\hline Renal & Flank pain, back pain, hematuria \\
\hline Neurological & Headache, dizziness, tunnel vision, 'feeling of impending doom' \\
\hline
\end{tabular}


display signs and symptoms similar to true hypersensitivity reactions; however, the hallmark of anaphylactoid or CRS reactions is that they occur with the first dose (i.e., first exposure) of a drug. The underlying mechanisms by which infusion reactions elicit clinical symptoms differ in important ways from a true antibody-mediated response [7]. Due to the asparaginase mechanism of action, iv. administration has been associated with a rapid rise in serum ammonium levels [69]. Symptoms of hyperammonemia may be similar to symptoms of clinical hypersensitivity and often include transient nausea, vomiting, headache, dizziness and rash $[70,71]$.

CRS is a specific type of infusion reaction that has been most often associated with the use of monoclonal antibodies and T-cell-engaging therapies $[33,35,36,72]$. Following drug infusion, a high-level activation of the immune system and engagement and proliferation of $T$ cells can result in increased cytokine release. Fever is a hallmark of infusion reactions, and therefore, many infusion reactions may mimic symptoms of an infection [72]. Other symptoms of infusion reactions include pruritus, rash, urticaria, headache, chills, fatigue, nausea and vomiting [7,33]. Unlike true antibody-mediated hypersensitivity reactions, anaphylactoid infusion reactions may occur on a patient's first exposure to the drug. In fact, the risk of CRS is greatest during a patient's initial exposure to monoclonal antibodies and decreases with repeated exposure [33]. Rituximab, an anti-CD20 monoclonal antibody used in the treatment of various leukemias and lymphomas, has been associated with infusion reactions in up to $77 \%$ of patients during first exposure, with $7 \%$ reported as grade $3 / 4$ [73,74]. The prevalence of infusion reactions decreased significantly during the later stages of therapy, with 30 and $14 \%$ displaying an infusion reaction following the fourth and eighth infusion, respectively (see case study 2) [74].

Blinatumomab is a bispecific T-cell-engaging antibody that redirects host $\mathrm{T}$ cells to target antigen-expressing cancer cells. In the pivotal Phase II study of blinatumomab in patients with ALL, $11 \%$ of individuals experienced a CRS reaction [75]. CAR T cells have also been associated with CRS in a number of patients [76]. In contrast to the rapid onset of CRS with monoclonal antibodies, CRS with CAR T-cell therapy may occur days or weeks following the initial infusion [72,77]. Patients with CRS in response to blinatumomab or CAR T-cell therapy have been found to show elevated levels of IL-6, IL-10 and INF- $\gamma$ [37].

Etoposide is a topoisomerase inhibitor that has been used in the treatment of patients with ALL and is associated with infusion reactions [78-81]. Anaphylactic-like reactions are characterized by chills, rigors, tachycardia, bronchospasm, dyspnea, diaphoresis, fever, pruritus, hypertension or hypotension, loss of consciousness, nausea and vomiting. Infusion reactions have been reported to occur in $3-34 \%$ of patients treated with etoposide [81,82]. Etoposide is typically infused within a 30- to 60-min session, and reactions have generally occurred during or shortly after the infusion. No IgE-antibody development has been associated with a reaction to etoposide, and up to $33 \%$ of reactions occur on the initial exposure [8]. Furthermore, clinical symptoms did not reoccur or increase in severity with repeated exposure, a characteristic that is suggestive of a nonantibody-mediated reaction [81].

\section{Treatment impact \& management}

Unless properly managed, infusion reactions can negatively affect treatment efficacy and outcomes. The effective identification and classification of hypersensitivity and infusion reactions is of critical importance to ensuring optimal outcomes in patients with ALL.

\section{- Clinical hypersensitivity reactions}

Clinical hypersensitivity reactions are associated with several negative effects on treatment efficacy and outcomes $[28,55,66,67]$. Patients who display clinical hypersensitivity (grade >2) must discontinue treatment with the offending drug, potentially preventing them from receiving the full benefit of therapy. Treatment discontinuation in the absence of viable alternative medications can have a negative effect on patient outcomes. In a report from the Dana-Farber Cancer Institute Consortium Protocol 91-01, investigators found that outcomes were significantly improved in patients who were able to tolerate at least 26 weeks of asparaginase treatment compared with patients who tolerated 25 weeks or fewer $(\mathrm{p}<0.01)$ [17]. Discontinuation due to clinical hypersensitivity was the most common reason for patients failing to receive at least 26 weeks of treatment in this study. Even in patients who continue treatment following hypersensitivity, changes in the immunogenic environment can negatively impact treatment 
efficacy. Patients who experienced a previous hypersensitivity event have been shown to exhibit higher concentrations of antidrug antibodies, display a shorter half-life, decreased area-under-the-curve and decreased drug levels, compared with patients who did not develop hypersensitivity $[28,55,66,67]$. Kurtzberg et al. evaluated E. coli-derived PEG-asparaginase activity in patients with ALL who had previously displayed hypersensitivity to native $E$. coli asparaginase [67]. The results showed that fewer patients treated with PEG-asparaginase in the hypersensitive group had detectable asparaginase levels at days 8 or 15 compared with the nonhypersensitive group, demonstrating a rapid clearance of asparaginase in patients with a history of hypersensitivity. Additionally, patients with a previous hypersensitivity event are likely to display a second hypersensitivity reaction if rechallenged $[41,66]$.

The development of antidrug antibodies in both clinical and subclinical hypersensitivity may also have indirect effects on other chemotherapeutic drugs administered as part of a multiagent chemotherapeutic regimen. In a study of 498 children with ALL treated according to the St Jude Total XV protocol, investigators found that patients who developed antiasparaginase antibodies also displayed increased dexamethasone clearance and lower overall dexamethasone exposure [83]. The investigators also showed through multivariate analysis that higher dexamethasone clearance and the presence of antiasparaginase antibodies were both independent risk factors for relapse [83].

Patients who develop systemic clinical hypersensitivity to chemotherapeutic agents should discontinue their current treatment. If clinical symptoms are manageable, physicians may attempt to rechallenge patients using antihistamine and general immunosuppressant prophylaxis. While this approach may reduce clinical symptoms, treatment efficacy may remain negatively impacted by the presence of antidrug antibodies and subclinical hypersensitivity. Whenever possible, patients who develop clinical or subclinical hypersensitivity should be switched to treatment with an immunologically distinct drug [29]. Patients who develop clinical or subclinical hypersensitivity to firstline therapy with native $E$. coli asparaginase and PEG-asparaginase and are switched to treatment with asparaginase $E$. chrysanthemi have been found to show comparable outcomes to patients who never experienced hypersensitivity $[16,41,64,66,84,85]$. Furthermore, studies have shown that the majority of patients who display immune reactions to $E$. coli-derived asparaginase are able to complete treatment once switched to asparaginase E. chrysanthemi $[84,85]$. The US FDA-approved dose substitution of asparaginase $E$. chrysanthemi for each planned dose of PEG-asparaginase is $25,000 \mathrm{IU} / \mathrm{m}^{2} \mathrm{im}$. or iv. administered threetimes per week (Monday/Wednesday/Friday) for six doses [86]. Ideally, patients who develop grade $\geq 2$ hypersensitivity to PEG asparaginase should be switched to asparaginase E. chrysanthemi as soon as symptoms resolve to avoid any possible gaps in asparagine depletion [29]. Successful rechallenge of the same formulation following hypersensitivity has been reported with various desensitization protocols; however, these measures are usually reserved for cases when asparaginase E. chrysanthemi is unavailable [87,88].

\section{- Subclinical hypersensitivity}

Due to the lack of clinical symptoms, patients with subclinical hypersensitivity often remain untreated. The identification and management of subclinical hypersensitivity requires the use of real-time therapeutic drug monitoring of asparaginase activity levels. A direct measurement of antiasparaginase antibodies is difficult in practice due to the lack of a commercially available assay; therefore, reduced asparaginase activity levels are often used as a proxy for neutralizing antibodies. Although no universal definition yet exists, several recent studies provide examples of the identification and management of subclinical hypersensitivity in patients undergoing asparaginase therapy for ALL $[16,66]$. Vrooman et al. evaluated asparaginase activity levels every 3 weeks in ALL patients initially treated with native $E$. coli asparaginase [16]. Subclinical hypersensitivity was defined as trough asparaginase activity levels $<0.1 \mathrm{IU} / \mathrm{ml}$ on successive measurements, despite the adjustment of dose. Tong et al. measured asparaginase activity, asparagine and glutamine levels and antiasparaginase antibodies in patients receiving PEG-asparaginase [66]. Silent inactivation was defined as serum PEGasparaginase activity levels $<0.10 \mathrm{U} / \mathrm{ml}$ at day 7 or $<0.02 \mathrm{U} / 1$ at day 14 after infusion in a patient without symptoms of clinical hypersensitivity. A recent report from Bleyer et al. 
suggests asparaginase activity levels $<0.05 \mathrm{U} / \mathrm{ml}$ obtained 3-5 days or 4-7 days postinfusion may be classified as displaying silent inactivation [89]. Although differences exist regarding the exact cutoffs for classification of subclinical hypersensitivity it is universally agreed that patients suspected of exhibiting subclinical hypersensitivity to an E. coli-derived asparaginase should be immediately switched to asparaginase E. chrysanthemi [90].

- Nonantibody-mediated infusion reactions Initial signs and symptoms of a nonantibodymediated infusion reaction are often difficult to distinguish from those of a true clinical hypersensitivity reaction [33]. True antibody-mediated reactions require previous exposure in order to drive antibody development, and therefore are unlikely to occur on a patient's first infusion. A diagnosis of nonantibody-mediated infusion reaction or CRS should be strongly considered in any patient who experiences a hypersensitivitylike reaction during their initial exposure. The exact time of symptom onset can also be useful in differentiating between these two different types of immune responses [46]. Anaphylactic reactions usually occur very rapidly, within seconds or minutes after the start of infusion. In contrast, symptoms of CRS typically occur within 30-120 min after infusion has been initiated and can manifest even later in the case of CAR T-cell therapies [33]. Educating the patient on the signs and symptoms of an immune reaction is also important, as delayed reactions have been reported [7].

Physicians should consider monitoring patients during all infusions and obtain vital signs throughout drug administration. Obtaining accurate measurements of baseline blood pressure is important as a recent treatment algorithm proposes hypotension as a key indicator in the decision to move forward with immunosuppressive treatment [72]. Once a reaction is suspected, the general consensus is that the infusion should be immediately discontinued and the patient treated with supportive care and additional immunosuppressive medication if necessary [7,72]. Following the resolution of all symptoms, patients may be successfully rechallenged at a slower infusion rate and with appropriate prophylactic medications [7,36,91-94].

Due to the nature of T-cell-engaging therapies, some degree of cytokine activation may be necessary for chemotherapeutic effect.
Symptom-specific management may be sufficient for low-grade CRS; however, more severe CRS reactions during CAR T-cell therapies may require intervention with vasopressors, corticosteroids, and other immunosuppressive agents [72]. Three specific cytokines, IL-6, IL-10 and INF- $\gamma$, have been identified as elevated in CRS during blinatumomab and CD19-specific CAR T-cell therapy [37,95]. The administration of the IL- 6 receptor-blocking agent tocilizumab has been associated with the reversal of potentially life-threatening CRS in a number of patients treated with CAR T-cell therapy and blinatumomab [13,39]. Fragmentation of the initial dose or reducing the infusion speed of blinatumomab can also lessen the severity or likelihood of CRS [37,38].

\section{Case studies}

- Case 1: grade 3 anaphylaxis (clinical hypersensitivity reaction)

A 5-year-old boy with initial diagnosis of pre-B-cell ALL (high risk by white blood cell count at diagnosis) underwent induction therapy according to the Children's Oncology Group AALL1131 protocol with decadron, weekly vincristine, daunorubicin and PEGasparaginase. Based on postinduction minimal residual disease, he was upstaged to very high risk and came to Pediatric Oncology Clinic for consolidation chemotherapy (day 15 per protocol) to receive intrathecal methotrexate, vincristine and PEG-asparaginase (second dose). He received his intrathecal meds and vincristine without event, but after receiving approximately one-third of a 1-h PEG-asparaginase infusion $(20 \mathrm{ml}$ of total $60 \mathrm{ml})$, he developed facial erythema, shortness of breath, nausea and vomiting. The asparaginase infusion was stopped immediately. Exam revealed lip and facial swelling; hives on his arm and chest; heart rate (HR): $140 \mathrm{bpm}$; respiration rate (RR): 30 ; oxygen saturation: $97 \%$; blood pressure (BP): $111 / 72 \mathrm{mmHg}$ and diffuse wheezing on auscultation but no stridor. Within minutes he received diphenhydramine $1 \mathrm{mg} / \mathrm{kg}$ iv., epinephrine $0.01 \mathrm{mg} / \mathrm{kg}$ subcutaneously and methylprednisolone $1 \mathrm{mg} / \mathrm{kg}$ iv., followed by normal saline fluid bolus of $20 \mathrm{ml} / \mathrm{kg}$ with good effect. Repeat vital signs showed HR: 120 bpm; RR: 20 and continued normal BP and oximetry. His wheezing was resolved, but his facial edema persisted, so he was admitted for observation overnight with regularly scheduled 
every-6-h dosing of diphenhydramine and methylprednisolone.

This reaction was classified by the attending physician as grade 3 anaphylaxis secondary to PEG-asparaginase because of the symptomatic bronchospasm with urticaria, angioedema and requirement for parenteral intervention with antihistamines, corticosteroids and epinephrine. This patient did not have hypotension noted. His subsequent treatment was modified by substitution of asparaginase E. chrysanthemi $\left(25,000 \mathrm{IU} / \mathrm{m}^{2}\right.$ given three-times per week (Monday/Wednesday/Friday) for 2 weeks (total of six doses) to replace each planned PEGasparaginase dose. This patient completed the remaining four courses of asparaginase therapy without evidence of allergy or further adverse event.

\section{- Case 2: grade 2 infusion-related reaction or cytokine-release syndrome}

A 7-year-old boy with a previous history of mature B-cell, CD20+ (Burkitt) leukemia was diagnosed with marrow relapse at his routine 6-month off-therapy clinic visit. Thus, rituximab was recommended as part of reinduction therapy, and he came to the Pediatric Infusion Center to begin this treatment. After premedication with acetaminophen and diphenhydramine, the rituximab infusion was started at $25 \mathrm{mg} / \mathrm{h}(0.5 \mathrm{mg} / \mathrm{kg} / \mathrm{h}) \times 60 \mathrm{~min}$ and then increased to $50 \mathrm{mg} / \mathrm{h}$ according to hospital guidelines. During the $50-\mathrm{mg} / \mathrm{h}$ infusion, the child experienced chills and rigors, so the infusion was stopped and restarted at the lower rate. The chills and rigors were suspected to be result of an infusion reaction, so after $1 \mathrm{~h}$ at the rate of $25 \mathrm{mg} / \mathrm{h}$ the rate was again increased to $50 \mathrm{mg} / \mathrm{h}$. $30 \mathrm{~min}$ later the patient complained of shortness of breath. He was noted to have two urticarial lesions on his arm with fever, tachycardia and mild hypotension, but no wheezing, stridor or respiratory distress (temperature: $38.5^{\circ} \mathrm{C}$; HR: $150 \mathrm{bpm}$; RR: 24; BP: $84 / 54 \mathrm{mmHg}$; oximetry: $98 \%)$. Chest X-ray was clear without pulmonary infiltrates. Laboratory results showed no evidence of tumor-lysis syndrome. He was medicated with additional doses of acetaminophen, diphenhydramine as well as a dose of methylprednisolone because of the drop in BP noted. After another pause of $30 \mathrm{~min}$, the infusion was continued at $25 \mathrm{mg} / \mathrm{h}$ without further difficulty. Hospitalization was recommended so that he could finish this dose at the slower rate with continuous careful monitoring of symptoms and vital signs for $24 \mathrm{~h}$. For his second infusion, he received premedication with acetaminophen, diphenhydramine and empiric corticosteroids; then the infusion was started at $25 \mathrm{mg} / \mathrm{h}(0.5 \mathrm{mg} / \mathrm{kg} / \mathrm{h})$ for the first hour. He again developed chills and urticarial lesions after the rate was increased to $100 \mathrm{mg} / \mathrm{h}$, but these symptoms cleared when the rate was decreased back to $50 \mathrm{mg} / \mathrm{h}$. Because the symptoms resolved at this rate, no further escalation was attempted. He tolerated his third and fourth doses with premedication, reaching the maximum rate of infusion of $400 \mathrm{mg} / \mathrm{h}$ with no further adverse events.

The symptoms of infusion reaction and hypersensitivity are similar and with considerable overlap, making them difficult to differentiate clinically; however, this case is most consistent with an infusion-related reaction, which is observed with the first dose, often rate-related, improving when the rate of infusion is slowed and decreasing in severity with subsequent doses. Because of the recurrence of symptoms after premedication, with development of urticarial lesions and drop in BP with only minimal dose escalation, his physician considered this a grade 2 infusion reaction (infusion interruption indicated but responds promptly to symptomatic treatment with antihistamines, NSAIDs, narcotics, iv. fluids and prophylactic medications needed for $\leq 24 \mathrm{~h}$, CTCAE v4.03) [34]. Fever, chills and rigors are typical of uncomplicated infusion reaction, but they also can occur in the setting of hypersensitivity or classic allergy. The appearance of shortness of breath, urticarial lesions, tachycardia and mild hypotension are more typical of antibody-mediated hypersensitivity, but can be associated with infusion reactions or a CRS, all of which have been reported with monoclonal antibodies (alemtuzumab, inotuzumab, rituximab among others) $[14,96,97]$. In addition, tumor-lysis syndrome or development of pulmonary infiltrates should be considered in this clinical scenario.

\section{Conclusion}

Symptoms of antibody-mediated hypersensitivity and nonantibody-mediated infusion reactions are often difficult to distinguish. Patients who experience a clinical hypersensitivity reaction should be switched to an immunologically 
distinct drug or discontinue therapy entirely, while patients who experience an infusion reaction or CRS can often continue treatment with proper management. As the ability to complete one's scheduled treatment is strongly linked to improved outcomes in patients with ALL, the accurate identification and management of infusion-related toxicities is of critical importance. A physician's understanding of the underlying physiological mechanisms of these different infusion-related toxicities will aid in treatment management decisions and improve long-term outcomes in patients with ALL.

\section{Future perspective}

The presence of antidrug antibodies is the primary factor distinguishing true clinical hypersensitivity reactions, which may necessitate the discontinuation of therapy and anaphylactoid infusion reactions, where patients can be rechallenged following the management of symptoms. Technological advances that allow for the rapid measurement of serum drug concentrations or antibody titers will soon play a larger role in assisting the physician in the classification and management of immunerelated adverse events. Furthermore, with the increased availability of real-time therapeutic drug measurement, physicians will be able to tailor therapies to the individual patient. Additional studies are needed to determine how individualized dosing might be used to increase patient tolerance, reduce chemotherapy-associated toxicity and optimize patient outcome.

Financial \& competing interests disclosure

$B$ Asselin is a consultant and a member of the Speakers Bureau for Jazz Pharmaceuticals, and a consultant for Sigma-Tau Pharmaceuticals. This work was funded by Jazz Pharmaceuticals. The author has no other relevant affliations or financial involvement with any organization or entity with a financial interest in or financial conflict with the subject matter or materials discussed in the manuscript apart from those disclosed.

The author wishes to thank Nancy Magnuson, MD, for reviewing this manuscript; and Cory Hussar, PhD, of The Curry Rockefeller Group, LLC, Tarrytown, NY, for providing editorial assistance that was supported by Jazz Pharmaceuticals.

\section{Open access}

This work is licensed under the Creative Commons Attribution-NonCommercial 4.0 Unported License. To view a copy of this license, visit http://creativecommons.org/ licenses/by-nc-nd/4.0/

\section{EXECUTIVE SUMMARY}

- Several chemotherapeutic drugs used in the treatment of patients with acute lymphoblastic leukemia are associated with infusion reactions.

- Infusion reactions can be dose limiting and may require the discontinuation of a specific therapy.

- There are two major categories of infusion reactions to chemotherapeutic drugs:

- Clinical hypersensitivity reactions are antibody-mediated immune reactions;

- Cytokine-release syndrome (CRS) commonly referred to as anaphylactoid reactions are nonantibody-mediated reactions characterized by histamine or cytokine release.

- Antibody-mediated immune reactions require previous exposure to a drug in order to induce antibody production in the host.

- CRS associated with monoclonal antibodies and T-cell-engaging immunotherapies often occur during the early stages of therapy and may occur during a patient's first exposure.

- Some patients develop antidrug antibodies in the absence of any overt clinical symptoms - this condition has been termed subclinical hypersensitivity or 'silent inactivation'.

- Both types of reactions exhibit similar clinical presentation and can be difficult to distinguish by symptoms alone.

- Patients who exhibit a grade $\geq 2$ clinical hypersensitivity reaction should be switched to treatment with an immunologically distinct chemotherapeutic agent whenever available.

- Patients who exhibit signs of a nonantibody-mediated infusion reaction or CRS may be rechallenged with the offending agent at a slower infusion rate and premedication with antihistamines and immune suppressants once symptoms have been successfully managed. 


\section{References}

Papers of special note have been highlighted as:

$\bullet$ of considerable interest

1 Siegel R, Naishadham D, Jemal A. Cancer statistics, 2012. CA Cancer J. Clin. 62(1), 10-29 (2012).

2 Inaba H, Greaves M, Mullighan CG. Acute lymphoblastic leukaemia. Lancet 381(9881), 1943-1955 (2013).

3 Pui CH, Robison LL, Look AT. Acute lymphoblastic leukaemia. Lancet 371(9617) 1030-1043 (2008)

4 Pui CH, Evans WE. Treatment of acute lymphoblastic leukemia. $N$. Engl. J. Med. 354(2), 166-178 (2006).

5 Asselin BL, Gaynon P, Whitlock JA. Recent advances in acute lymphoblastic leukemia in children and adolescents: an expert panel discussion. Curr. Opin. Oncol. 25(Suppl. 3), S1-S13 (2013).

6 Pui CH, Mullighan CG, Evans WE, Relling MV. Pediatric acute lymphoblastic leukemia: where are we going and how do we get there? Blood 120(6), 1165-1174 (2012).

7 Lenz HJ. Management and preparedness for infusion and hypersensitivity reactions. Oncologist 12(5), 601-609 (2007).

8 Shepherd GM. Hypersensitivity reactions to chemotherapeutic drugs. Clin. Rev. Allergy Immunol. 24(3), 253-262 (2003).

9 Syrigou E, Makrilia N, Koti I, Saif MW, Syrigos KN. Hypersensitivity reactions to antineoplastic agents: an overview. Anticancer Drugs 20(1), 1-6 (2009).

10 Joerger M. Prevention and handling of acute allergic and infusion reactions in oncology. Ann. Oncol. 23(Suppl. 10), x313-x319 (2012).

11 Shinnick SE, Browning ML, Koontz SE. Managing hypersensitivity to asparaginase in pediatrics, adolescents, and young adults. J. Pediatr. Oncol. Nurs. 30(2), 63-77 (2013).

12 Asselin BL, Fisher V. Impact of clinical and subclinical hypersensitivity to asparaginase in acute lymphoblastic leukemia. Clin. J. Oncol. Nurs. 18(6), E107-E112 (2014).

13 Teachey DT, Rheingold SR, Maude SL et al. Cytokine release syndrome after blinatumomab treatment related to abnormal macrophage activation and ameliorated with cytokine-directed therapy. Blood 121(26), 5154-5157 (2013)

14 Jabbour E, O’Brien S, Ravandi F, Kantarjian $\mathrm{H}$. Monoclonal antibodies in acute lymphoblastic leukemia. Blood 125(26), 4010-4016 (2015).
15 Maude SL, Shpall EJ, Grupp SA. Chimeric antigen receptor T-cell therapy for ALL. Hematol. Am. Soc. Hematol. Educ. Program 2014(1), 559-564 (2014).

16 Vrooman LM, Stevenson KE, Supko JG et al. Postinduction dexamethasone and individualized dosing of Escherichia coli L-asparaginase each improve outcome of children and adolescents with newly diagnosed acute lymphoblastic leukemia: results from a randomized study - DanaFarber Cancer Institute ALL Consortium Protocol 00-01. J. Clin. Oncol. 31(9), 1202-1210 (2013).

-• Randomized clinical trial highlighting the benificts of individualized dosing treatment regimens in newly diagnosed patients with acute lymphoblastic leukemia.

17 Silverman LB, Gelber RD, Dalton VK et al. Improved outcome for children with acute lymphoblastic leukemia: results of DanaFarber Consortium Protocol 91-01. Blood 97(5), 1211-1218 (2001).

-• Showed that failure to receive at least 26 weeks of asparaginase therapy was an independent predictor of adverse outcomes.

18 Panosyan EH, Seibel NL, Martin-Aragon S et al. Asparaginase antibody and asparaginase activity in children with higher-risk acute lymphoblastic leukemia: Children’s Cancer Group Study CCG-1961. J. Pediatr. Hematol. Oncol. 26(4), 217-226 (2004).

19 Sompayrac M. How the Immune System Works (Fourth Edition). Wiley-Blackwell (John Wiley \& Sons, Ltd), Hoboken, NJ, USA (2012).

20 Solomon S, Komanduri K. The immune system. In: Biotherapy: A Comprehensive Overview. Rieger PT (Ed.). Jones \& Bartlett Learning, LLC, Sudbury, MA, USA, 39-63 (2001).

21 Murphy K, Travers P, Walport M (Eds). Janeway's Immunobiology. Garland Science, Taylor \& Frances Group, LLC, New York, NY, USA (2008).

22 Ream MA, Tunison D. Hypersensitivity reactions. In: Nursing Management of Symptoms Associated With Chemotherapy. Yasko JM (Ed.). Meniscus Health Care, Bala Cynwyd, PA, USA, 213-224 (2001).

23 Abbas AK, Lichtman AH. Cellular and Molecular Immunology. Saunders, Philadelphia, PA, USA (2003).

24 Avramis VI, Avramis EV, Hunter W, Long MC. Immunogenicity of native or pegylated E. coli and Erwinia asparaginases assessed by ELISA and surface plasmon resonance
(SPR-biacore) assays of IgG antibodies (Ab) in sera from patients with acute lymphoblastic leukemia (ALL). Anticancer Res. 29(1), 299-302 (2009).

25 Zalewska-Szewczyk B, Andrzejewski W, Mlynarski W, Jedrychowska-Danska K, Witas $\mathrm{H}$, Bodalski J. The anti-asparagines antibodies correlate with L-asparagines activity and may affect clinical outcome of childhood acute lymphoblastic leukemia. Leuk. Lymphoma 48(5), 931-936 (2007).

26 Korholz D, Wahn U, Jurgens H, Wahn V. Allergic reactions in treatment with $\mathrm{L}$-asparaginase. Significance of specific IgE antibodies. Monatsschr. Kinderheilkd.138(1), 23-25 (1990).

27 Ring J, Brockow K, Behrendt H. History and classification of anaphylaxis. Novartis Found. Symp. 257, 6-16; discussion 16-24, 45-50, 276-285 (2004).

28 Asselin BL, Whitin JC, Coppola DJ, Rupp IP, Sallan SE, Cohen HJ. Comparative pharmacokinetic studies of three asparaginase preparations. J. Clin. Oncol. 11(9), 1780-1786 (1993).

29 Burke MJ. How to manage asparaginase hypersensitivity in acute lymphoblastic leukemia. Future Oncol. 10(16), 2615-2627 (2014).

30 Asselin B, Rizzari C. Asparaginase pharmacokinetics and implications of therapeutic drug monitoring. Leuk. Lymphoma 56(8), 2273-2280 (2015).

31 Jaing TH, Lin JL, Lin YP, Yang SH, Lin JJ, Hsia SH. Hyperammonemic encephalopathy after induction chemotherapy for acute lymphoblastic leukemia. J. Pediatr. Hematol. Oncol. 31(12), 955-956 (2009).

32 Nussbaum V, Lubcke N, Findlay R. Hyperammonemia secondary to asparaginase: a case series. J. Oncol. Pharm. Pract. 22(1), 161-164 (2016).

33 Vogel WH. Infusion reactions: diagnosis, assessment, and management. Clin. J. Oncol. Nurs. 14(2), E10-E21 (2010).

34 National Cancer Institute. (2010). Common Terminology Criteria for Adverse Events (CTCAE). Version 4.03. NIH Publication No. 09-5410, 14 June 2010. http://evs.nci.nih.gov

35 Kang SP, Saif MW. Infusion-related and hypersensitivity reactions of monoclonal antibodies used to treat colorectal canceridentification, prevention, and management. J. Support. Oncol. 5(9), 451-457 (2007).

36 Breslin S. Cytokine-release syndrome: overview and nursing implications. Clin. J. Oncol. Nurs. 11(1 Suppl.), 37-42 (2007). 
37 Klinger M, Brandl C, Zugmaier G et al. Immunopharmacologic response of patients with B-lineage acute lymphoblastic leukemia to continuous infusion of $\mathrm{T}$ cell-engaging CD19/CD3-bispecific BiTE antibody blinatumomab. Blood 119 (26), 6226-6233 (2012).

38 Topp MS, Kufer P, Gokbuget N et al. Targeted therapy with the T-cell-engaging antibody blinatumomab of chemotherapyrefractory minimal residual disease in B-lineage acute lymphoblastic leukemia patients results in high response rate and prolonged leukemia-free survival. J. Clin. Oncol. 29(18), 2493-2498 (2011).

39 Grupp SA, Kalos M, Barrett D et al. Chimeric antigen receptor-modified $\mathrm{T}$ cells for acute lymphoid leukemia. N. Engl. J. Med. 368(16), 1509-1518 (2013).

40 Maude SL, Frey N, Shaw PA et al. Chimeric antigen receptor $\mathrm{T}$ cells for sustained remissions in leukemia. N. Engl. J. Med. 371(16), 1507-1517 (2014).

41 Woo MH, Hak LJ, Storm MC et al. Hypersensitivity or development of antibodies to asparaginase does not impact treatment outcome of childhood acute lymphoblastic leukemia. J. Clin. Oncol. 18(7), 1525-1532 (2000).

42 Myers JS. Complications of cancer and cancer treatment. In: Oncology Nursing. Langhorne ME, Fulton JS, Ortto SE (Eds). Mosby, St Louis, MO, USA, 402-453 (2007).

43 Van Gerpen R. Chemotherapy and biotherapy-induced hypersensitivity reactions. J. Infus. Nurs. 32(3), 157-165 (2009).

44 Holms Gobel B, O’Leary C. Hypersensitivity reactions to antineoplastic drugs. In: Cancer Nursing: Principles and Practice. Yarbro $\mathrm{CH}$, Wujcik D, Holms Gobel B (Eds). Jones \& Bartlett Publishers, LLC, Sudbury, MA, USA, 792-806 (2011).

45 Ben-Shoshan M, Clarke AE. Anaphylaxis: past present and future. Allergy 66(1), 1-14 (2011).

46 Lieberman P, Nicklas RA, Oppenheimer J et al. The diagnosis and management of anaphylaxis practice parameter: 2010 update. J. Allergy Clin. Immunol. 126(3), 477-480, e1-e42 (2010).

47 Petersen W, Clark D, Senn S, Cash T, Keller F, Lew G. Pegaspargase administration in children with acute lymphoblastic leukemia. Presented at: The American Society of Pediatric Hematology Oncology. New Orleans, LA, USA, 9-12 May 2012.

48 Hunger S, COG Pharmacy Committee. Parental and oral chemotherapy administration guidelines used by the Children's Oncology Group (Version 6). In: Archives of the Children's Oncology Group. Children's Oncology Group, Acadia, CA, USA (2010).

49 Muller HJ, Boos J. Use of L-asparaginase in childhood ALL. Crit. Rev. Oncol. Hematol. 28(2), 97-113 (1998).

50 Nesbit M, Chard R, Evans A, Karon M, Hammond GD. Evaluation of intramuscular versus intravenous administration of L-asparaginase in childhood leukemia. Am. J. Pediatr. Hematol. Oncol. 1(1), 9-13 (1979).

51 Henriksen LT, Harila-Saari A, Ruud E et al. PEG-asparaginase allergy in children with acute lymphoblastic leukemia in the NOPHO ALL2008 protocol. Pediatr. Blood Cancer 62(3), 427-433 (2015)

52 Petersen WC Jr., Clark D, Senn SL et al. Comparison of allergic reactions to intravenous and intramuscular pegaspargase in children with acute lymphoblastic leukemia. Pediatr. Hematol. Oncol. 31(4), 311-317 (2014).

53 Albertsen BK, Schroder H, Jakobsen P et al. Antibody formation during intravenous and intramuscular therapy with Erwinia asparaginase. Med. Pediatr. Oncol. 38(5), 310-316 (2002).

54 Albertsen BK, Schroder H, Ingerslev J et al. Comparison of intramuscular therapy with Erwinia asparaginase and asparaginase Medac: pharmacokinetics, pharmacodynamics, formation of antibodies and influence on the coagulation system. $\mathrm{Br}$. J. Haematol. 115(4), 983-990 (2001).

55 Liu C, Kawedia JD, Cheng C et al. Clinical utility and implications of asparaginase antibodies in acute lymphoblastic leukemia. Leukemia 26(11), 2303-2309 (2012).

56 Avramis VI, Sencer S, Periclou AP et al. A randomized comparison of native Escherichia coli asparaginase and polyethylene glycol conjugated asparaginase for treatment of children with newly diagnosed standard-risk acute lymphoblastic leukemia: a Children's Cancer Group study. Blood 99(6), 1986-1994 (2002).

57 Wang B, Relling MV, Storm MC et al. Evaluation of immunologic crossreaction of antiasparaginase antibodies in acute lymphoblastic leukemia (ALL) and lymphoma patients. Leukemia 17(8), 1583-1588 (2003).

58 Avramis VI, Panosyan EH. Pharmacokinetic/ pharmacodynamic relationships of asparaginase formulations: the past, the present and recommendations for the future. Clin. Pharmacokinet. 44(4), 367-393 (2005).
59 Keding R. RE: Discontinuation of Elspar ${ }^{\circledR}$, (asparaginase for injection) 10,000 IU. Lundbeck LLC, Deerfield, IL, USA (August 2012). www.fda.gov

60 Hawkins DS, Park JR, Thomson BG et al. Asparaginase pharmacokinetics after intensive polyethylene glycol-conjugated L-asparaginase therapy for children with relapsed acute lymphoblastic leukemia. Clin. Cancer Res. 10(16), 5335-5341 (2004).

61 Vrooman LM, Kirov II, Dreyer ZE et al. Activity and toxicity of intravenous Erwinia asparaginase following allergy to E. coliderived asparaginase in children and adolescents with acute lymphoblastic leukemia. Pediatr. Blood Cancer 63(2), 228-233 (2016).

62 Chen SH, Pei D, Yang W et al. Genetic variations in GRIA1 on chromosome 5q33 related to asparaginase hypersensitivity. Clin. Pharmacol. Ther. 88(2), 191-196 (2010).

63 Fernandez CA, Smith C, Yang W et al. Genome-wide analysis links NFATC2 with asparaginase hypersensitivity. Blood 126(1), 69-75 (2015).

64 Pieters R, Hunger SP, Boos J et al. $\mathrm{L}$-asparaginase treatment in acute lymphoblastic leukemia: a focus on Erwinia asparaginase. Cancer 117(2), 238-249 (2011).

65 Asselin BL. The three asparaginases. Comparative pharmacology and optimal use in childhood leukemia. Adv. Exp. Med. Biol. 457, 621-629 (1999).

66 Tong WH, Pieters R, Kaspers GJ et al. A prospective study on drug monitoring of PEGasparaginase and Erwinia asparaginase and asparaginase antibodies in pediatric acute lymphoblastic leukemia. Blood 123(13), 2026-2033 (2014).

67 Kurtzberg J, Asselin B, Bernstein M, Buchanan GR, Pollock BH, Camitta BM. Polyethylene glycol-conjugated L-asparaginase versus native L-asparaginase in combination with standard agents for children with acute lymphoblastic leukemia in second bone marrow relapse: a Children's Oncology Group Study (POG 8866). J. Pediatr. Hematol. Oncol. 33(8), 610-616 (2011).

68 Willer A, Gerss J, Konig T et al. AntiEscherichia coli asparaginase antibody levels determine the activity of second-line treatment with pegylated $E$ coli asparaginase: a retrospective analysis within the ALLBFM trials. Blood 118(22), 5774-5782 (2011).

69 Heitink-Polle KM, Prinsen BH, de Koning TJ, van Hasselt PM, Bierings MB. High 
incidence of symptomatic hyperammonemia in children with acute lymphoblastic leukemia receiving pegylated asparaginase. JIMD Rep. 7, 103-108 (2013).

70 Jorck C, Kiess W, Weigel JF, Mutze U, Bierbach U, Beblo S. Transient hyperammonemia due to L-asparaginase therapy in children with acute lymphoblastic leukemia or non-Hodgkin lymphoma. Pediatr. Hematol. Oncol. 28(1), 3-9 (2011).

71 Howard S, Szwiec K, Buddington K, Ewing $\mathrm{H}$. The weaned pig as a model for asparaginase infusion reactions. Pediatr. Blood Cancer 62 (Suppl 2), Abstract 698, doi:10.1002/pbc.25540 (2015).

72 Lee DW, Gardner R, Porter DL et al. Current concepts in the diagnosis and management of cytokine release syndrome. Blood 124(2), 188-195 (2014).

73 Kimby E. Tolerability and safety of rituximab (MabThera). Cancer Treat. Rev. 31(6), 456-473 (2005).

74 Davis TA, Grillo-Lopez AJ, White CA et al. Rituximab anti-CD20 monoclonal antibody therapy in non-Hodgkin's lymphoma: safety and efficacy of re-treatment. J. Clin. Oncol. 18(17), 3135-3143 (2000).

75 Topp MS, Gokbuget N, Zugmaier G et al. Phase II trial of the anti-CD19 bispecific $\mathrm{T}$ cell-engager blinatumomab shows hematologic and molecular remissions in patients with relapsed or refractory B-precursor acute lymphoblastic leukemia. J. Clin. Oncol. 32(36), 4134-4140 (2014).

76 Lee DW, Kochenderfer JN, Stetler-Stevenson $\mathrm{M}$ et al. $\mathrm{T}$ cells expressing $\mathrm{CD} 19$ chimeric antigen receptors for acute lymphoblastic leukaemia in children and young adults: a phase 1 dose-escalation trial. Lancet 385(9967), 517-528 (2015).

77 McLaughlin L, Cruz CR, Bollard CM. Adoptive T-cell therapies for refractory/ relapsed leukemia and lymphoma: current strategies and recent advances. Ther. Adv. Hematol. 6(6), 295-307 (2015).

78 Chen CL, Rawwas J, Sorrell A, Eddy L, Uckun FM. Bioavailability and pharmacokinetic features of etoposide in childhood acute lymphoblastic leukemia patients. Leuk. Lymphoma 42(3), 317-327 (2001).
79 Hijiya N, Gajjar A, Zhang Z et al. Low-dose oral etoposide-based induction regimen for children with acute lymphoblastic leukemia in first bone marrow relapse. Leukemia 18(10), 1581-1586 (2004).

80 Hudson MM, Weinstein HJ, Donaldson SS et al. Acute hypersensitivity reactions to etoposide in a VEPA regimen for Hodgkin's disease. J. Clin. Oncol. 11(6), 1080-1084 (1993).

81 Kellie SJ, Crist WM, Pui CH et al. Hypersensitivity reactions to epipodophyllotoxins in children with acute lymphoblastic leukemia. Cancer 67(4), 1070-1075 (1991).

82 Etopophos $^{\circledR}$ (etoposide phosphate) [prescribing information]. Bristol-Myers Squibb Company, Princeton, NJ, USA (July 2015).

http://packageinserts.bms.com

83 Kawedia JD, Liu C, Pei D et al. Dexamethasone exposure and asparaginase antibodies affect relapse risk in acute lymphoblastic leukemia. Blood 119 (7), 1658-1664 (2012).

84 Salzer WL, Asselin B, Supko JG et al. Erwinia asparaginase achieves therapeutic activity after pegaspargase allergy: a report from the Children's Oncology Group. Blood 122(4), 507-514 (2013).

- Results of the pivotal COG AALL07P2 clinical trial of patients treated with asparaginase Erwinia chrysanthemi $25,000 \mathrm{IU} / \mathrm{m}^{2}$ on a Monday, Wednesday, Friday schedule.

85 Plourde PV, Jeha S, Hijiya N et al. Safety profile of asparaginase Erwinia chrysanthemi in a large compassionate-use trial. Pediatr. Blood Cancer 61(7), 1232-1238 (2014).

86 Erwinaze $^{\circledR}$ (asparaginase Erwinia chrysanthemi) [prescribing information]. Jazz Pharmaceuticals, Inc, Palo Alto, CA, USA (December 2014). www.erwinaze.com/ERWINAZEPI.pdf

87 Akbayram S, Dogan M, Akgun C, Caksen H, Oner AF. A desensitization protocol in children with L-asparaginase hypersensitivity. J. Pediatr. Hematol. Oncol. 32(5), e187-e191 (2010).
88 Tong WH, Pieters R, Tissing WJ, van der Sluis IM. Desensitization protocol should not be used in acute lymphoblastic leukemia patients with silent inactivation of PEGasparaginase. Haematologica 99(7), e102-e104 (2014).

89 Bleyer A, Asselin BL, Koontz SE, Hunger SP. Clinical application of asparaginase activity levels following treatment with pegaspargase. Pediatr. Blood Cancer 62 (6), 1102-1105 (2015).

90 van der Sluis IM, Vrooman LM, Pieters R et al. Consensus expert recommendations for identification and management of asparaginase hypersensitivity and silent inactivation. Haematologica 101(3), 279-285 (2016).

91 Zanotti KM, Markman M. Prevention and management of antineoplastic-induced hypersensitivity reactions. Drug Saf. 24(10), 767-779 (2001)

92 Joint Task Force on Practice Parameters, American Academy of Allergy, Asthma and Immunology, American College of Allergy, Asthma and Immunology, and the Joint Council of Allergy, Asthma and Immunology. The diagnosis and management of anaphylaxis. J. Allergy Clin. Immunol. 101(6 Pt 2), S465-S528 (1998).

93 Peereboom DM, Donehower RC, Eisenhauer EA et al. Successful re-treatment with taxol after major hypersensitivity reactions. J. Clin. Oncol. 11(5), 885-890 (1993).

94 Dillman RO. Infusion reactions associated with the therapeutic use of monoclonal antibodies in the treatment of malignancy. Cancer Metastasis Rev. 18(4), 465-471 (1999).

95 Kalos M, Levine BL, Porter DL et al. T cells with chimeric antigen receptors have potent antitumor effects and can establish memory in patients with advanced leukemia. Sci. Transl. Med. 3(95), 95ra73 (2011).

96 Rituxan ${ }^{\circledR}$ (rituximab) [prescribing information]. Genentech, Inc., South San Francisco, CA, USA (2013). www.gene.com

97 Campath ${ }^{\circledR}$ (alemtuzumab) [prescribing information]. Genzyme Corporation, Cambridge, MA, USA (2014). www.campath.com 